\title{
PROFIL PERESEPAN OBAT PADA PASIEN RAWAT JALAN JAMKESDA DARI POLI KARDIOVASKULAR DI APOTEK RUMAH SAKIT LABUANG BAJI MAKASSAR PERIODE JANUARI - JUNI 2014
}

\author{
Audi Triani Olii, Nurlina, Hilyatun Niswah \\ Fakultas Farmasi Universitas Muslim Indonesia \\ Email : audhee_jie@yahoo.com
}

\begin{abstract}
Study of Drugs Prescribing Profile In Outpatient Jamkesda of Poly Cardiovaskular In Labuang Baji Hospital Makassar period January - June 2014 has done. The aim of this study is to obtain the secondary data and than analyzing themby administration screening, pharmaceutical screening and clinical screening. This study was descriptive type with retrospective data which taken from secondary data on Outpatient Jamkesda of Poly Cardiovaskular In Labuang Baji Hospital Makassar period January - June 2014. Based on the results of this study, concluded that from 5617 of prescription sheets of Jamksda outpatient were included in the study period, 508 sheets recipe comes from Cardiovascular Poly (9\%) which 52,4\% from that recipe is male patients, $32,1 \%$ are $51-60$ years, $89,2 \%$ without doctor's initials, 23,2\% of prescription contain 5 different drugs, $74,8 \%$ of prescription contain diuretics as the first choice of therapy, and there is a 1133 cases of drug interaction cases.
\end{abstract}

Key words : Prescribing Profile, Cardiovascular, Screening Recipe.

\section{PENDAHULUAN}

Penyakit

kardiovaskular

merupakan penyebab utama mortalitas

di dunia. Prevalensi penyakit kardiovaskular cenderung meningkat dari tahun ke tahun. Angka kematian akibat penyakit kardiovaskular di seluruh dunia adalah $29,3 \%$ dari semua penyebab kematian (Hastuti, 2009). Organisasi Kesehatan Dunia (WHO) melaporkan satu dari tiga orang di seluruh dunia pada tahun 2001, meninggal karena penyakit kardiovaskular (WHO, 2004).
Di Indonesia penderita penyakit jantung berdasarkan hasil Survei Kesehatan Rumah Tangga (SKRT) 2002, penyakit jantung menempati urutan utama sebagai penyebab kematian dan diperkirakan angka ini akan meningkat setiap tahunnya. Melihat prevalensinya, perlu dilihat bagimana pola peresepan yang ada sehingga dapat meminimalkan kematian akibat penyakit jantung.

Menurut hasil penelitian Bakri (2011) menunjukkan bahwa dari 1019 lembar resep dari pasien rawat jalan 
Profil Peresepan Obat Pada Pasien Rawat Jalan Jamkesda Dari Poli Kardiovaskular Di Apotek Rumah Sakit Labuang Baji Makassar Periode Januari - Juni 2014

jamkesmas dari poli kardiovaskular di

RSUP H. Adam malik Medan, diperoleh bahwa interaksi obat terjadi $28,85 \%$. Berdasarkan inilah perlu dilakukan penelitian tentang profil peresepan obat kardiovaskular di Makassar.

Ini menjadi perhatian melihat semakin meningkatnya pasien penyakit jantung serta belum terdapatnya data tentang profil peresepan obat kardiovaskular khususnya di daerah Makassar. Oleh karena itu, perlu dilakukan penelitian tentang profil peresepan obat pada pasien rawat jalan Jamkesda dari Poli kardiovaskular di Apotek Rumah Sakit Labuang Baji Makassar untuk mengetahui apakah resep-resep tersebut telah sesuai dengan ketentuan yang berlaku.

\section{METODOLOGI PENELITIAN}

Tempat dan Waktu Penelitian

Penelitian ini dimulai bulan Maret - Juli 2014 dan bertempat di Apotek Rawat Jalan Rumah Sakit Labuang Baji Makassar.

\section{Populasi dan Sampel}

Populasi penelitian adalah semua resep pada pasien rawat jalan Jamkesda di Apotek Rumah Sakit Labuang Baji Makassar. Dan sampel penelitian adalah resep obat pada pasien rawat jalan Jamkesda dari poli kardiovaskular di Apotek Rumah Sakit Labuang Baji Makassar periode Januari - Juni 2014.

\section{Metode Kerja}

\section{Desain Penelitian}

Penelitian ini bersifat deskriptif dengan jenis data penelitian adalah retrospektif. Data yang diambil adalah data sekunder yaitu resep pada pasien rawat jalan Jamkesda dari poli kardiovaskular di Apotek Rumah Sakit Labuang Baji Makassar periode Januari - Juni 2014.

\section{Tahapan Penelitian}

\section{Penelitian Pendahuluan}

Dilakukan orientasi untuk mengetahui berapa persen dari semua resep pasien rawat jalan Jamkesda di Apotek Rumah Sakit Labuang Baji Makassar yang berasal dari poli kardiovaskular.

\section{Identifikasi variabel serta data yang diperlukan}

1. Banyaknya resep pasien rawat jalan Jamkesda

2. Banyaknya resep pasien dari Poli Kardiovaskular

3. Kelompok umur

4. Jenis kelamin

5. Kelengkapan administrasi

6. Kesesuaian dosis

7. Golongan obat yang digunakan

8. Jumlah obat dalam satu resep

9. Interaksi yang tejadi 
Profil Peresepan Obat Pada Pasien Rawat Jalan Jamkesda Dari Poli Kardiovaskular Di Apotek Rumah Sakit Labuang Baji Makassar Periode Januari - Juni 2014

\section{Pengambilan Data}

1. Dikumpulkan semua resep rawat jalan Jamkesda yang masuk pada periode penelitian.

2. Dipilih resep dari poli kardiovakular

\section{HASIL PENELITIAN}

Tabel.1 Jumlah lembar resep Jamkesda periode Januari-Juni 2014 di Apotek Rawat Jalan Rumah Sakit Labuang Baji Makassar

\begin{tabular}{cccc}
\hline Bulan & Jumlah Resep & Poli Kardiovaskular & Persentase (\%) \\
\hline Januari & 1017 & 108 & 10.1 \\
Februari & 987 & 96 & 9.7 \\
Maret & 976 & 87 & 8.9 \\
April & 947 & 72 & 7.6 \\
Mei & 918 & 77 & 8.4 \\
Juni & 772 & 68 & 8.8 \\
\hline
\end{tabular}

Tabel.2 Profil Identitas Pasien berdasarkan jenis kelamin pada Lembar Resep Rawat Jalan Jamkesda dari Poli Kardiovaskular di Rumah Sakit Labuang Baji Makassar

\begin{tabular}{ccc}
\hline Jenis kelamin & Jumlah & Persentase (\%) \\
\hline Pria & 266 & 52.4 \\
Wanita & 242 & 47.6 \\
\hline Total & $\mathbf{5 0 8}$ & $\mathbf{1 0 0}$ \\
\hline
\end{tabular}

Tabel.3 Profil Identitas Pasien berdasarkan umur pada Lembar Resep Rawat Jalan Jamkesda dari Poli Kardiovaskular di Rumah Sakit Labuang Baji Makassar

\begin{tabular}{ccc}
\hline Identitas Umur (Tahun) & Jumlah & Persentase (\%) \\
\hline $10-20$ & 7 & 1.4 \\
$21-30$ & 22 & 4.3 \\
$31-40$ & 13 & 2.6 \\
$41-50$ & 126 & 24.8 \\
$51-60$ & 163 & 32.1 \\
$61-70$ & 149 & 29.3 \\
$71-80$ & 18 & 3.5 \\
$81-90$ & 0 & 0 \\
$91-100$ & 10 & 2.0 \\
\hline Total & $\mathbf{5 0 8}$ & $\mathbf{1 0 0}$ \\
\hline
\end{tabular}


Profil Peresepan Obat Pada Pasien Rawat Jalan Jamkesda Dari Poli Kardiovaskular Di Apotek Rumah Sakit Labuang Baji Makassar Periode Januari - Juni 2014

Tabel.4 Profil kelengkapan administrasi pada Lembar Resep Rawat Jalan Jamkesda dari Poli Kardiovaskular di Rumah Sakit Labuang Baji Makassar

\begin{tabular}{clcccc}
\hline \multirow{2}{*}{ No } & Kelengkapan & \multicolumn{2}{c}{ Jumlah Resep } & \multicolumn{2}{c}{ Persentase (\%) } \\
\cline { 3 - 6 } & \multicolumn{1}{c}{ Resep } & Ada & Tidak ada & Ada & Tidak Ada \\
\hline 1 & Nama Dokter & 503 & 5 & 99.0 & 1.0 \\
2 & Paraf Dokter & 55 & 453 & 10.8 & 89.2 \\
3 & Nama Pasien & 504 & 4 & 99.2 & 0.8 \\
4 & Alamat Pasien & 0 & 508 & 0 & 100 \\
5 & Umur Pasien & 59 & 449 & 11.6 & 88.4 \\
6 & Tanggal Resep & 501 & 7 & 98.6 & 1.4 \\
7 & Jenis Kelamin & 240 & 268 & 47.2 & 52.8 \\
8 & Berat Badan & 0 & 508 & 0 & 100 \\
9 & Dosis & 404 & 104 & 79.5 & 20.5 \\
10 & Jumlah satuan Obat & 507 & 1 & 99.8 & 0.2 \\
11 & Aturan Pakai & 507 & 1 & 99.8 & 0.2 \\
\hline
\end{tabular}

Tabel.5 Profil Kesesuaian Dosis pada Lembar Resep Rawat Jalan Jamkesda dari Poli Kardiovaskular di Rumah Sakit Labuang Baji Makassar

\begin{tabular}{cccc}
\hline No & Jenis Dosis & Jumlah Obat & Persentase (\%) \\
\hline 1 & Dosis Tepat & 1420 & 92,4 \\
2 & Dosis Berlebih & 1 & 0,06 \\
3 & Dosis Kurang & 106 & 6,9 \\
4 & Dosis tidak diketahui & 16 & 1,0 \\
\hline \multicolumn{2}{c}{ Total } & $\mathbf{1 5 4 3}$ & $\mathbf{1 0 0}$ \\
\hline
\end{tabular}

Tabel.6 Profil Jumlah Obat dalam Satu Lembar Resep pada Resep Rawat Jalan Jamkesda dari Poli Kardiovaskular di Rumah Sakit Labuang Baji Makassar

\begin{tabular}{ccc}
\hline Jumlah Obat Perlembar Resep & Jumlah Resep (resep) & Persentase (\%) \\
\hline 1 obat & 9 & 1.8 \\
2 obat & 18 & 3.5 \\
3 obat & 49 & 9.6 \\
4 obat & 79 & 15.6 \\
5 obat & 118 & 23.2 \\
6 obat & 112 & 22.0 \\
7 obat & 57 & 11.2 \\
8 obat & 32 & 6.3 \\
9 obat & 15 & 3.0 \\
10 obat & 15 & 3.0 \\
11 obat & 3 & 0.6 \\
12 obat & 1 & 0.2 \\
\hline Total & $\mathbf{5 0 8}$ & $\mathbf{1 0 0}$
\end{tabular}


Profil Peresepan Obat Pada Pasien Rawat Jalan Jamkesda Dari Poli Kardiovaskular Di Apotek Rumah Sakit Labuang Baji Makassar Periode Januari - Juni 2014

Tabel.7 Profil Golongan Obat pada Lembar Resep Rawat Jalan Jamkesda dari Poli Kardiovaskular di Rumah Sakit Labuang Baji Makassar

\begin{tabular}{clcc}
\hline No & \multicolumn{1}{c}{ Golongan Obat } & Jumlah lembar Resep & Persentase (\%) \\
\hline 1 & Inhibitor ACE & 99 & 19.5 \\
2 & Angiotensin Reseptor Bloker & 266 & 52.3 \\
3 & Diuretik & 380 & 74.8 \\
4 & Glikosida Jantung & 77 & 15.2 \\
5 & $\beta$-Bloker & 145 & 28.5 \\
6 & a-Bloker & 0 & 0 \\
7 & Penyekat Kanal Na & 0 \\
8 & Penyekat Kanal Ca++ & 0 & 37.0 \\
9 & Penyekat Kanal K+ & 188 & 0 \\
10 & Nitrat Organik & 0 & 43.3 \\
11 & Obat-obat Hiperlipidemia & 220 & 33.0 \\
\hline
\end{tabular}

Tabel.8 Profil Interaksi Obat pada Lembar Resep Rawat Jalan Jamkesda dari Poli Kardiovaskular di Rumah Sakit Labuang Baji Makassar

\begin{tabular}{|c|c|c|c|c|}
\hline \multirow{2}{*}{$\begin{array}{c}\text { No } \\
1\end{array}$} & \multicolumn{2}{|c|}{ Interaksi Obat } & \multirow{2}{*}{$\begin{array}{c}\text { Tingkat } \\
\text { Keparahan } \\
\text { Interaksi }\end{array}$} & \multirow{2}{*}{$\begin{array}{c}\text { Frekuensi } \\
11\end{array}$} \\
\hline & Glikosida Jantung & Inhibitor Pompa Proton & & \\
\hline 2 & Glikosida Jantung & Diuretik & Minor & 81 \\
\hline 3 & Glikosida Jantung & Inhibitor ACE & Moderete & 25 \\
\hline 4 & Glikosida Jantung & NSAID & Moderete & 33 \\
\hline 5 & ARB & Diuretik & Major & 18 \\
\hline 6 & ARB & Benzodiazepin & Moderete & 18 \\
\hline 7 & ARB & NSAID & Moderete & 122 \\
\hline 8 & ARB & Sedatif Ringan & Moderete & 5 \\
\hline 9 & Diuretik & NSAID & Minor & 177 \\
\hline 10 & Diuretik & Inhibitor Pompa Proton & Moderete & 77 \\
\hline 11 & Diuretik & B-Bloker & Moderete & 61 \\
\hline 12 & Diuretik & Inhibitor ACE & Moderete & 33 \\
\hline 13 & Diuretik & Diabetes Melitus & Moderete & 1 \\
\hline 14 & Diuretik & Anti Platelet & Minor & 48 \\
\hline 15 & Diuretik & Sedatif Ringan & Moderete & 6 \\
\hline 16 & Diuretik & Benzodiazepin & Moderete & 20 \\
\hline 17 & Diuretik & Antibiotik & Moderete & 2 \\
\hline 18 & Diuretik & Penyekat Kanal Ca & Minor & 16 \\
\hline 19 & Nitrat Organik & Inhibitor ACE & Moderete & 28 \\
\hline 20 & Nitrat Organik & Inhibitor Pompa Proton & Minor & 22 \\
\hline 21 & Obat Hiperlipidemik & Inhibitor Pompa Proton & Moderete & 40 \\
\hline 22 & Obat Hiperlipidemik & Penyekat Kanal Ca & Major & 58 \\
\hline
\end{tabular}


Profil Peresepan Obat Pada Pasien Rawat Jalan Jamkesda Dari Poli Kardiovaskular Di Apotek Rumah Sakit Labuang Baji Makassar Periode Januari - Juni 2014

\begin{tabular}{lllcc}
23 & Anti Platelet & Inhibitor Pompa Proton & Moderete & 36 \\
24 & Penyekat Kanal Ca & B-Bloker & Moderete & 63 \\
25 & Penyekat Kanal Ca & Inhibitor Ace & Minor & 25 \\
26 & Penyekat Kanal Ca & NSAID & Moderete & 21 \\
27 & B-Bloker & NSAID & Minor & 76 \\
28 & B-Bloker & Benzodiazepin & Moderete & 8 \\
29 & B-Bloker & Sedatif Ringan & Moderete & 2 \\
\hline \multicolumn{2}{r}{ Total } \\
\hline
\end{tabular}

\section{PEMBAHASAN}

Pada penelitian kali ini, peneliti melakukan skrining resep terhadap resep pasien Jamkesda rawat jaalan dari kardiovaskular di Apotek Rumah Sakit Labuang Baji Makassar pada periode Januari - Juni 2014. Penelitian ini dilakukan pada bulan Juni sampai dengan Juli 2014 di Apotek Rawat Jalan Rumah Sakit Labuang Baji Makassar. Penelitian bersifat deskriptif dengan jenis data restrospektif.

Seperti yang di jelaskan sebelumnya bahwa pada penelitian ini akan dilakukan skrining resep yang meliputi skrining administrasi, skrining farmasetik dan skrining klinis terhadap sampel penelitian.

Resep yang masuk pada periode penelitian berjumlah 5617 lembar dan yang berasal dari poli kardiovaskular berjumlah 508 lembar, yang berarti 9,04\% dari resep yang masuk merupakan resep dari poli kardiovaskular. Hasil yang diperoleh menjelaskan bahwa rata-rata pasien rawat jalan yang berobat di Poli
Kardiovaskular Rumah Sakit Labuang Baji Makssar sebesar 9 \%. Hasil pengamatan mengenai jumlah resep Jamkesda periode Januari - Juni 2014 dapat dilihat pada tabel.1

Salah satu faktor resiko penyakit kardiovaskular adalah jenis kelamin. Hasil ini dapat di lihat pada tabel 2. Hasil yang di dapatkan sesuai dengan literatur yang manyatakan bahwa pria lebih beresiko terkena penyakit kardiovaskular dibandingkan wanita. Laki-laki mempunyai resiko lebih tinggi untuk menderita kardiovaskular di awal. Di Amerika Serikat gejala penyakit jantung sebelum umur 60 tahun di dapatkan pada 1 dari 5 adalah laki-laki dan 1 dari 17 adalah perempuan. Ini berarti bahwa laki-laki mempunyai resiko penyakit jantung lebih besar terhadap morbiditas dan mortilitas kardiovaskular (Wika, 2008).

Faktor resiko penyakit kardiovaskular yang lainnya adalah umur. Dimana pada penelitian kali ini resep di kelompokkan berdasarkan 
Profil Peresepan Obat Pada Pasien Rawat Jalan Jamkesda Dari Poli Kardiovaskular Di Apotek Rumah Sakit Labuang Baji Makassar Periode Januari - Juni 2014

umur pasien. Hasil ini dapat dilihat tabel.3. Dari hasil penelitian dapat di lihat bahwa pasien dengan umur $\geq 41$ tahun lebih dominan dibandingkan dengan pasien dengan umur $\leq 40$ tahun. Peningkatan morbiditas dan mortilitas kardiovsakular mulai terjadi pada kelompok usia 30-44 tahun, semakin bertambah umur maka semakin beresiko. Kematian pada usia dini yaitu $<64$ tahun atau 25-64 tahun. Walaupun kematian karena kardiovakular lebih banyak terjadi pada usia >65 tahun, namun penyebab kematian pada kelompok usia tua sulit di interprestasikan karena adanya faktor penyebab penyakit lain (Anwar, 2004).

Identifikasi berikutnya adalah skrining adaministrasi untuk melihat kelangkapan resep yang dijadikan sampel penelitian. Penelitian ini dilakukan dengan cara memeriksa satu per satu kelengkapan resep dan dilakukan pengumpulan data. Hasil ini dapat dilihat pada tabel 4. Dari hasil penelitian dapat diketahui bahwa resep yang ada belum mememenuhi persyaratan administrasi yang di tetapkan oleh Keputusan menteri kesehatan Republik Indonesia nomor 1197/MENKES/SK/X/2004 tentang standar pelayanan kefarmasian di Rumah sakit. Dimana alamat pasien, berat badan dan jenis kelamin secara berurutan berada pada urutan teratas bagian resep yang tidak di tulis oleh dokter yakni sebesar $100 \%$. Penulisan alamat pasien sangatlah penting agar ketika terjadi kesahalan pada saat pelayanan resep apoteker yang bertugas dapat langsung melacak alamat pasien. Urutan tertinggi kedua bagian yang tidak lengkap adalah tidak adanya paraf atau tanda tangan dokter pada resep yakni sebesar $89,2 \%$. Hal ini sangatlah penting agar ketika terjadi kesalahan pada penulisan resep apoteker dapat langsung mengkonfirmasi kepada dokter yang bersangkutan. Berikutnya adalah tidak tercantumnya dosis pada resep yakni sebesar 20,5\%, mengingat adanya obat yang sama namun memiliki kekuatan yang berbeda maka dokter perlu untuk menulis kekuatan obat pada resep.

Identifikasi selanjutnya yang dilakukan adalah skrining farmasetik yaitu evaluasi dosis yang di tulis oleh dokter. Dimana pada penelitian ini akan ditentukan dosis tepat, dosis kurang, dosis berlebih dan dosis tidak diketahui. Rincian data yang diperoleh dapat dilihat pada tabel.5. Berdasarkan hasil di atas dapat dilihat bahwa dokter menulis dosis yang tepat sesuai dengan dosis terapi yang 
Profil Peresepan Obat Pada Pasien Rawat Jalan Jamkesda Dari Poli Kardiovaskular Di Apotek Rumah Sakit Labuang Baji Makassar Periode Januari - Juni 2014

dibutuhkan untuk pengobatan pasien. Adapun data yang di peroleh disesuaikan dengan dosis pada pustaka Katzung (2006). Dosis kurang dihasilkan paling banyak oleh obat Bisoprolol dimana pada pustaka tertera bahwa dosis terapi untuk obat ini adalah $5 \mathrm{mg} /$ hari sedangkan yang tertera pada resep adalah $2,5 \mathrm{mg} /$ hari. $\mathrm{Hal}$ ini dapat dipengaruhi oleh beberapa faktor, salah satunya yakni bahwa bisoprolol bukan merupakan obat utama melainkan obat tambahan. Kemudian untuk resep yang tidak diketahui artinya bahwa dalam resep tersebut tidak tertera dosis obat. Tetapi biasanya ada kesepakatan tidak tertulis antara dokter dengan apoteker bahwa jika dosis obat tidak tertulis maka diberikan obat dengan dosis yang terkecil.

Selanjutnya adalah identifikasi jumlah obat dalam satu lembar resep. Dimana hasil yang dapat di lihat pada tabel 6. Pada tabel 6 dapat dilihat bahwa kombinasi obat banyak ditemukan pada penelitain ini. Dengan persentase tertinggi 5 obat yakni sebanyak 118 lembar atau $23,2 \%$, kemudian di susul dengan 6 obat sebanyak 112 lembar atau 22,0\%. Dalam penelitian ini juga ditemukan resep yang mengandung 12 jenis obat, di mana obat-obat tersebut adalah
Aspilet $^{\circledR}, \quad$ Clopidogrel, Isosorbid Dinitrat, $\quad$ Farsorbid $^{\circledR}$, Simvastatin, Candesartan, Amlodipin, Furosemid, Sohobion $\quad 5000^{\circledR}, \quad$ Lansoprazol, Bisoprolol dan Gemfibrozil. Terapi polifarmasi atau pemberian obat yang berlebih biasanya diberikan oleh dokter untuk mengurangi keluhankeluhan lainnya dan meningkatkan potensi kerja obat, namun peluang terjadi efek samping meningkat, interaksi antar obat dalam satu resep semakin besar, dan tingkat kepatuhan pasien semakin berkurang (Harianto, 2006).

Identifikasi berikutnya yang dilakukan adalah penggolongan obat kardiovaskular yang di gunakan dalam resep. Rincian data yang diperoleh dapat dilihat pada tabel 7 . Berdasarkan hasil yang diperoleh golongan obat kardiovaskular yang paling sering diresepkan dokter untuk pengobatan adalah golongan diuretik yakni sebanyak 380 lembar resep. Dimana yang menjadi pilihan utama adalah Furosemid sebanyak 275 lembar $(72,4 \%)$ dari total lembaran resep yang menggunakan obat golongan diuretik, sisanya adalah spironolakton dan Hidroklortiazid masing-masing 84 lembar $(22,1 \%)$ dan 21 lembar $(5,5 \%)$. Diuretik dan atau penyekat $-\beta$ sering diberikan sebagai 
Profil Peresepan Obat Pada Pasien Rawat Jalan Jamkesda Dari Poli Kardiovaskular Di Apotek Rumah Sakit Labuang Baji Makassar Periode Januari - Juni 2014

terapi hipertensi lini pertama. Terapi diuretik dosis rendah aman dan efektif untuk menghindari stroke, infark miokard, gagal jantung kongestif dan mortilitas. Data-data terakhir menunjukkan diuretika lebih pemakaiannya daripada penyekat- $\beta$ pada umur-umur lanjut (FUB, 2001).

Pilihan golongan obat berikutnya yang paling sering $\mathrm{di}$ resepkan adalah golongan Angiotensin Reseptor Bloker (ARB) yakni sebanyak 266 lembar. Dimana yang menjadi pilihan utama golongan obat ini adalah candesartan yakni sebanyak 206 lembar $(77,4 \%)$ dari total lembar resep yang menggunakan obat golongan ARB sisanya adalah valsartan sebanyak 37 lembar (14\%) dan Micardis ${ }^{\circledR}$ (Telimsartan) sebanyak 23 lembar $(0,8 \%)$. Nitrat Organik merupakan salah satu golongan obat yang sering di resepkan dokter yakni sebanyak 220 lembar, dimana obat yang paling banyak digunakan adalah Farsorbid sebanyak 115 lembar $(52,2 \%)$ darti total lembaran resep yang mengandung obat golongan Nitrat Organik sisanya adalah Isosorbid Dinitrat sebanyak 60 lembar $(27,2 \%)$ dan Nitrokaf sebanyak 45 lembar (20,6\%).

Identifikasi selanjutnya yang di lakukan adalah skrining klinis, pada penelitian ini skrining klinis dilakukan terhadap jumlah interaksi obat yang terjadi pada sampel lembaran resep tersebut. Suatu interaksi bisa terjadi ketika efek suatu obat diubah oleh kehadiran obat lain, obat herbal, makanan, minuman atau agen kimia lainnya dalam lingkungan. Definisi ini lebih relevan adalah ketika obat bersaing satu dengan yang lainnya, atau yang terjadi ketika satu obat hadir bersama dengan obat yang lainnya (Stockley, 2008). Adapun rincian data yang diperoleh yang diperleh pada penelitian ini dapat dilihat pada tabel.8. Interaksi Obat ditelusuri dengan menggunakan sistem Drugs.com. Berdasarkan tabel.7 diatas dapat dilihat bahwa interaksi obat yang terjadi dari 508 lembar resep yang dikumpulkan adalah sebanyak 1133 kasus. Dimana jumlah tersebut terdiri atas 3 tingkatan severitas interaksi yakni minor, moderete, dan major. Dari 1133 interaksi yang terjadi sebanyak 445 kasus $(39,3 \%)$ bersifat minor 612 kasus $(54,0 \%)$ bersifat moderete dan 76 kasus (6,7\%) bersifat major. Keparahan/severitas interaksi dapat diklasifikasikan kedalam tiga level yaitu minor, moderate dan mayor. Sebuah interaksi termasuk dalam keparahan minor jika interaksi mungkin terjadi tetapi di pertimbangkan 
Profil Peresepan Obat Pada Pasien Rawat Jalan Jamkesda Dari Poli Kardiovaskular Di Apotek Rumah Sakit Labuang Baji Makassar Periode Januari - Juni 2014

signifikan potensial berbahaya ARB dengan obat golongan terhadap pasien jika terjadi kelainan, sebuah interaksi termasuk dalam keparahan moderete jika satu dari bahaya potensial mungkin terjadi pada pasien dan beberapa tipe intervensi/monitor sering diperlukan, efek interaksi moderate mungkin menyebabkan perubahan status klinis pasien, menyebabkan perawatan tambahan, perawatan di Rumah Sakit dan atau perpanjangan lama tinggal di Rumah Sakit, dan sebuah interaksi termasuk dalam severitas major jika terdapat probabilitas yang tinggi kejadian yang membahayakan pasien termasuk kejadian yang menyangkut nyawa pasien dan terjadinya kerusakan permanen (Bailie, 2004).

Dari hasil tersebut severitas yang paling banyak terjadi adalah moderete, salah contoh kasus interaksi yang paling sering muncul pada setiap lembaran resep adalah obat golongan Angiotensin Reseptor Bloker (ARB) dengan golongan Anti Inflamasi Non Steroid (AINS). Untuk severitas kecil salah satu contoh kasus interaksi yang sering muncul adalah interaksi antara obat golongan Diuretik dengan golongan AINS. Dan untuk severitas besar kasus interaksi yang sering muncul adalah interaksi obat golongan

hiperlipidemik.

\section{KESIMPULAN}

Berdasarkan hasil diatas dapat disimpulkan bahwa dari 508 lembar resep pasien rawat jalan Jamkesda dari poli Kardiovaskular di Apotek Rumah Sakit Labuang Baji Makassar periode Januari - Juni 2014 sebesar $52,4 \%$ resep adalah pasien pria, $32,1 \%$ resep adalah pasien dengan umur 51 - 60 tahun, 89,2\% resep tidak mengandung paraf dokter, $23,2 \%$ resep menggunakan 5 jenis obat dalam satu lembar resep, 74,8\% resep menggunakan golongan obat diuretik sebagai pilihan pertama terapi, dan ditemukan kasus interaksi obat sebanyak 1133 kasus.

\section{DAFTAR PUSTAKA}

Anief, Moh., 2010. IImu Meracik Obat Teori dan Praktik. Gadjah Mada University Press, Yogyakarta.

Anwar, T. Bahri., 2004. Faktor Resiko Penyakit Jantung Koroner. Fakultas Kedokteran Universitas Sumatera Utara, Medan.

Bailie, G.R., Jhonson, C.A., Masaon, N. A., Peter, W.L.St. 2004. Medfact Pocket Guide of Drug Interaction. Second EditionBone Care International, Nephorology Pharmacy Associated, Middleton 
Profil Peresepan Obat Pada Pasien Rawat Jalan Jamkesda Dari Poli Kardiovaskular Di Apotek Rumah Sakit Labuang Baji Makassar Periode Januari - Juni 2014

Bakri, Teddy Kurniawan., 2011, 'Profil Peresepan Obat pada Pasien Rawat Jalan Jamkesmas dari Poli Kardiovaskular Di Rumah Sakit Umum Pusat Haji Adam Malik Medan Periode JanuariMaret 2011', Skripsi, Fakultas Farmasi, Universitas Sumatera Utara, Medan.

Corwin, Elizabeth J., 2009. Buku Saku Patofisiologi Edisi 3. Penerbit Buku Kedokteran - EGC, Jakarta.

Dipiro, Joseph T. Talbert, Robert L. Yee, Gary C. Matzake, Gary R. Wells, Barbara G. Posey, L. Michael., 2008. Pharmacotherapy A Pathophysiologic Approach, Seventh Edition. Mc Graw Hill MEDICAL, New York Chicago.

Gunawan, Sulistia Gan., 2007. Farmakologi dan Terapi, Edisi 5. Departemen Farmakologi dan Terapeutik Fakultas Kedokteran - Universitas Indonesia, Jakarta.

Hasib, A., 2011. 'Peranan Farmasi Sebagai Pemberi Informasi Obat di Apotek Rumah sakit Umum Daerah Labuang Baji Makassar', Skripsi, Kementerian Kesehatan Republik Indonesia Politeknik Kesehatan Makassar, Makassar.

Harianto., 2006. Hubungan Antara Kualifikasi Dokter dengan Kerasionalam Penulisam Resep Obat Oral Kardiovaskular Pasien Dewasa di Tinjau dari Sudut Interaksi Obat (Studi Kasus di Apotek "x" Jakarta Timur),
Majalah IImu Kefarmasian, Vol.III, No.2 : 66-77.

Hapasari., Fierdini, L.N., 2011. 'Pola Peresepan dan Kerasionalan Penggunaan Antimikroba Pada Pasien Balita di Puskesmas Kecamatan Jatinegara'. Skripsi, Fakultas MIPA., Universitas Indonesia, Jakarta.

Hastuti, Janatin. Rahmawati, Neni T. Suriyanto, Rusyad Adi. Nuryana Tri., 2004. 'Relevansi Beberapa Ukuran Antropometrik dan Komposisi Badan Terhadap Faktor Risiko Penyakit Kardiovaskuler pada Penduduk Daerah Istimewa Yogyakarta' Laporan Akhir Penelitian Dosen Muda,. Fakultas Kedokteran, Universitas Gadjah Mada, Yogyakarta.

Joanes, Z. N., 2001. Ars Prescribendi - Resep yang Rasional, Edisi 2. Airlangga University Press, Surbaya.

Katzung, Bertram G., 2006. Farmakologi Dasar Dasar dan Klinik. Edisi 10. Penerbit Buku Kedokter-EGC, Jakarta.

Keputusan Menteri Kesehatan RI Nomor

1197/MENKES/SK/X/2004

Mengenai Standar Pelayanan Kefarmasian Di Rumah Sakit. Jakarta.

Departemen Kesehatan RI.

Mycek, J. Mary. Harvey, A. Richard. Champe, C. Pamela., 2001. Farmakologi Ulasan Bergambar, Edisi 2. Widya Medika, Jakarta. 
Profil Peresepan Obat Pada Pasien Rawat Jalan Jamkesda Dari Poli Kardiovaskular Di Apotek Rumah Sakit Labuang Baji Makassar Periode Januari - Juni 2014

Neal, M. J., 2003. At a Glance Farmakologi Medis, Edisi 5. Erlangga Medical Series EMS, Surabaya.

Notoatmodjo, S., 2002. Metedeologi Penelitian Kesehatan, Cetakan ke 2. PT Rineka Cipta, Jakarta.

Sanjoyo, Raden., 2005. 'Sistem Kardiovaskular'. Fakultas MIPA, Univeritas Gadjah Mada, Yogyakarta.

Sloane, Ethel., 2003. Anatomi Dan Fisiologi Untuk Pemula. Penerbit Buku Kedokteran EGC, Jakarta.

Sukandar, Elin Yulinah. Andrajati, Retnosari. Sigit, I Joseph. Adnyana, I Ketut. Setiadi, Adji Prayitno. Kusnandar, Dr.,
2008. Iso Farmakoterapi. PT. ISFI Penerbitan, Jakarta.

Syamsuni, H. 2005., Farmasetika Dasar dan Hitungan Farmasi. Penerbit Buku Kedokteran EGC, Jakarta.

World Health Organization, 2004. The Atlas Heart Disease and Stroke. Volume 84. New York, WHO.

Wika., 2008. Perempuan Monopause Rentan Terkena Jantung Koroner.., Diakses pada tanggal 7 Agustus 2014. www.mediaindonesia.com/beri ta.asp?id=16038.

Zainuddin., 1999. Metode Penelitian. Universitas Airlangga Press, Surabaya. 